\title{
Autoantibodies and neuropsychiatric manifestations in childhood-onset systemic lupus erythematosus
}

\author{
Mariana Postal ${ }^{1}$, Aline Lapa ${ }^{1}$, Nailu Sinicato ${ }^{1}$, Roberto Marini ${ }^{2}$, Simone Appenzeller ${ }^{1 *}$ \\ From 21st European Pediatric Rheumatology (PReS) Congress \\ Belgrade, Serbia. 17-21 September 2014
}

\begin{abstract}
Introduction
Neuropsychiatric manifestations are considered to be a serious complication in childhood-onset systemic lupus erythematosus (cSLE). The pathogenesis of neuropsychiatric manifestations has been attributed to autoantibodymediated neural dysfunction.
\end{abstract}

\section{Objectives}

To investigate the prevalence and associations of neuropsychiatric manifestations with antiribosomal $\mathrm{P}$ protein antibodies, S100 $\beta$, subunit of high molecular weight neurofilament (NF-H), antiphospholipid [anticardiolipin $(\mathrm{aCL})$ and lupus anticoagulant (LA)], anti-dsDNA and anti-Smith.

\section{Methods}

We included consecutive cSLE followed at the pediatric rheumatology unit of the State University of Campinas. Neurological manifestations were analyzed according to the ACR classification criteria. Cognitive evaluation was performed in all participants using Wechsler Intelligence Scale for children (WISC-III) and Wechsler Intelligence Scale for adults (WAIS), according to age and validated in Portuguese. Mood disorders were determined through Becks Depression and Anxiety Inventory in all participants. SLE patients were further assessed for clinical and laboratory SLE manifestations, disease activity [SLE Disease Activity Index (SLEDAI)], damage [Systemic Lupus International Collaborating Clinics/American College of Rheumatology Damage Index (SDI)] and current drug exposures. Antiribosomal P protein antibodies, $S 100 \beta$ and NF-H were tested by ELISA using commercial kits. The

${ }^{1}$ Medicine, State University of Campinas, Campinas, Brazil

Full list of author information is available at the end of the article levels of dsDNA antibodies were determined by indirect immunofluorescence using Crithidiaas a substrate and were considered positive if they were higher than 110 . The levels of precipitating antibodies to extractable nuclear antigens (ENA), including Sm, were detected using a standardized enzyme-linked immunosorbent assay (ELISA) method and were considered positive if higher than 180. The levels of IgG and IgM anticardiolipin antibodies (aCL) were measured by ELISA. Lupus anticoagulant (LA) activity was detected by coagulation assays in platelet-free plasma obtained by double centrifugation following the recommendations of the Scientific and Standardization Committee of the International Society of Thrombosis and Homeostasis subcommittee on LA Antiphospholipid (aCL and LA), anti-dsDNA and antiSmith were obtained of the medical charts. Data were compared by non-parametric tests.

\section{Results}

We included 77 cSLE patients (69 women; mean age 17.64 \pm 4.64 years). The mean disease duration was $4.35 \pm 3.9$ years . At time of study entry, 33 (42.85\%) cSLE patients had active disease (mean SLEDAI scores 3.58 \pm 3.97 ; range 0-14). Eighteen (23.37\%) cSLE had cumulative damage (mean SDI scores $0.35 \pm 0.67$; range 1-3). We observed neuropsychiatric manifestations in 49 (63.63\%) cSLE. The most frequent manifestations observed in our cohort were cognitive impairment (46.93\%), depression (36.73\%) and seizure (24.48\%). Mean NF-H protein levels were 101.80 $\pm 89.40 \mathrm{pg} / \mathrm{mL}$ and mean serum S100 $\beta$ levels were 148.98 $\pm 102.73 \mathrm{pg} / \mathrm{mL}$ in $\mathrm{cSLE}$. antiP were positive in 13 (16.8\%), aCL in 15 (19.5\%), LA in 29 (37.7\%), dsDNA in $31(40.3 \%)$ and anti-Sm in $11(14.3 \%)$ cSLE patients. 
We did not observe an association between the presence of neuropsychiatric manifestations and any of the tested autoantibodies.

\section{Conclusion}

Although frequently observed in cSLE antiribosomal $\mathrm{P}$ protein antibodies, aCL and LA, anti-dsDNA and anti-Smith, S100B and NF-H are not good biomarkers for neuropsychiatric manifestations.

\section{Disclosure of interest}

M. Postal: None declared., A. Lapa: None declared., N. Sinicato: None declared., R. Marini: None declared., S. Appenzeller Grant / Research Support from: FAPESP (2008/02917-0, 2011/03788-2, 2013/09480-5); CNPQ (300447/2009-4 and 471343/2011-0; 302205/2012-8; 473328/2013-5).

\section{Authors' details}

${ }^{1}$ Medicine, State University of Campinas, Campinas, Brazil. ${ }^{2}$ Pediatrics, State

University of Campinas, Campinas, Brazil.

Published: 17 September 2014

doi:10.1186/1546-0096-12-S1-P114

Cite this article as: Postal et al:: Autoantibodies and neuropsychiatric manifestations in childhood-onset systemic lupus erythematosus.

Pediatric Rheumatology 2014 12(Suppl 1):P114.
Submit your next manuscript to BioMed Central and take full advantage of:

- Convenient online submission

- Thorough peer review

- No space constraints or color figure charges

- Immediate publication on acceptance

- Inclusion in PubMed, CAS, Scopus and Google Scholar

- Research which is freely available for redistribution

Submit your manuscript at www.biomedcentral.com/submit 